\title{
Isprepletanje istraživačkih odluka i teorijskog utemeljenja: primjer jednog istraživanja kolektivnih sjećanja
}

\author{
Tanja VUČKOVIĆ JUROŠ \\ Studijski centar socijalnog rada, Pravni fakultet Sveučilišta u Zagrebu \\ tanja.vuckovic.juros@gmail.com
}

\begin{abstract}
U radu se na primjeru jednog istraživanja kolektivnih sjećanja prikazuje kako su proces donošenja istraživačkih odluka, pristup specifičnom istraživačkom području te operacionalizacija problema kolektivnih sjećanja ovisili o teorijskoj utemeljenosti na trima razinama. Prva, razina sociološke teorijske perspektive (u ovom slučaju društvenoga konstruktivizma) odredila je pristup kolektivnim sjećanjima i njihovu individualističku konceptualizaciju. Takva je konceptualizacija u dominantnim semiotičkim i institucionalnim pristupima kolektivnim sjećanjima bila zanemarena. Druga razina, razina metodološkog pristupa dovela je do uporabe kvalitativnih metoda unutar društvenokonstruktivističkog pristupa. Konačno, treća razina bila je razina aktualnih teorijskih promišljanja o kolektivnim sjećanjima što je dovelo do »otkrivanja« problema u trenutačnim pristupima te do konceptualizacije konkretnih istraživačkih pitanja. Na kraju se u radu pokušava pokazati kako određeni odgovori na tako postavljena istraživačka pitanja mogu općenito pridonijeti aktualnim teorijskim promišljanjima na području kolektivnih sjećanja te popuniti uočeni »nedostatak«. Na taj se način prikazuje kako je kvalitativni pristup kolektivnim sjećanjima pridonio tom području pružajući novo razumijevanje problema oblikovanja kolektivnih sjećanja, u čemu su dominantni semiotički i institucionalni pristupi bili manje uspješni.
\end{abstract}

Ključne riječi: teorija, društveni konstruktivizam, kvalitativne metode, kolektivna sjećanja, individualistička konceptualizacija

\section{Uvod}

U odnosu kvalitativnih istraživanja i teorije često se pojavljuje određena napetost.* U hrvatskom kontekstu, jedan od razloga tomu jest još uvijek

\footnotetext{
* Ranija verzija ovog rada izložena je na godišnjoj konferenciji Hrvatskoga sociološkog društva (HSD) u Zagrebu u lipnju 2012. Zahvaljujem sudionicima na komentarima, a posebne zahvale idu Karin Doolan na njezinom pomnom promišljanju problema teorije i kvalitativnih metoda. Istraživanje koje se koristi kao primjer u ovom radu djelomice je
} 
dominantna kvantitativna tradicija u kojoj vladavina koncepata poput opovrgljivih hipoteza ili reprezentativnoga slučajnog uzorka katkad dovodi do gotovo automatskog odbacivanja teorijskih potencijala bilo kakvoga drukčijeg tipa istraživanja. Donekle, to je stanje naslijeđe marksističke perspektive koja je dominirala ovim područjem u razdoblju socijalizma i koja nije dopuštala kritičke refleksije i alternativne epistemologije i metodologije, poput interpretativnih pristupa ili kvalitativne metodologije (Tomić-Koludrović, 2009). No, tom problemu također pridonose i neki kvalitativni istraživači koji sami preuzimaju dominantni diskurs te svoje rezultate ograničuju frazama koje napominju kako je ovo istraživanje samo eksplorativno ili kako se ti rezultati ne mogu uopćiti na cijelu populaciju (te su time, implicira se, manje vrijedni od rezultata koji se mogu uopćiti na taj način). Dakako, ovakve pozicije zanemaruju činjenicu da dobra kvalitativna istraživanja, kao i ona kvantitativna, stoje na solidnim teorijskim temeljima i da njihovi rezultati doprinose daljnjem razumijevanju teorijskih problema. Putovi kojima se pritom kreću kvalitativna i kvantitativna istraživanja možda jesu drukčiji, ali zato svako od njih ima svoju vrijednost unutar okvira različitih prednosti i slabosti. Odgovornost je svakog istraživača eksplicirati utemeljenje i doprinos vlastitog istraživanja području kojim se bavi ili pak nekoj široj teorijskoj perspektivi, ako to postavke istraživanja omogućuju. Upravo zbog prethodno spomenutih pogrešnih percepcija o vezi kvalitativnih istraživanja $i$ teorije, odgovornost kvalitativnih istraživača u njihovu ekspliciranju još je veća.

Stoga je cilj ovog rada na primjeru jednog istraživanja kolektivnih sjećanja prikazati kako je proces donošenja istraživačkih odluka o pristupu kolektivnim sjećanjima, specifičnom istraživačkom problemu unutar tog područja te operacionalizaciji problema bio teorijski utemeljen te kako rezultati samog istraživanja dalje doprinose teoriji kolektivnih sjećanja. Donekle, ovaj će tekst imati određeni ispovjedni ton. Iako to nije uobičajena konvencija znanstvenog pisanja, takav je ton u radu ovog tipa nužan. Naime, ovim se radom prelazi »s pozornice« (eng. front stage) izvještavanja o konceptualizaciji istraživanja i njegovim rezultatima u prostor »iza pozornice« (eng. backstage) (Goffman, 1956) gdje se događa proces koji je doveo do znanstvenog produkta. Dakle, u ovom radu, pobliže ću se ba-

financirano s Doctoral Dissertation Improvement Grant broj 0825225 američke National Science Foundation (NSF) i sa Stipendijom za doktorande Hrvatske zaklade za znanost (HRZZ). 
viti teorijskom utemeljenošću svog istraživanja na trima razinama. Prva je razina sociološke teorijske perspektive, u ovom slučaju pozicije društvenog konstruktivizma, koja je odredila moj pristup kolektivnim sjećanjima i njihovu konceptualizaciju. Druga je razina metodološkog pristupa koja je dovela do usmjeravanja prema kvalitativnom pristupu unutar društvenokonstruktivističkog pristupa kolektivnima sjećanjima. Konačno, treća razina jest razina aktualnih teorijskih promišljanja o kolektivnim sjećanjima koja je dovela do »otkrivanja « problema u trenutačnim pristupima kolektivnim sjećanjima te do konceptualizacije mojih vlastitih istraživačkih pitanja. Na kraju rada pokušat ću prikazati kako specifični odgovori na tako postavljena istraživačka pitanja mogu općenito pridonijeti aktualnim teorijskim promišljanjima o kolektivnim sjećanjima te popuniti uočeni »nedostatak« u razumijevanju ovog područja. Na taj način, u zaključku ovog izlaganja prikazat ću kako je kvalitativni pristup kolektivnim sjećanjima pridonio ovom području pružajući jedno novo razumijevanje problema formiranja kolektivnih sjećanja kakvo dominantni semiotički i institucionalni pristupi kolektivnim sjećanjima nisu mogli ponuditi.

\section{Teorijska perspektiva: kamo me usmjerio društvenokon- struktivistički pristup?}

Moja primarna teorijska sociološka identifikacija jest pozicija društvenog konstruktivizma ili interpretativizma, kako je neki nazivaju (Crotty, 1998). ${ }^{1}$ Ovo, dakako, ima nekoliko posljedica za moje razumijevanje društva, no u ovom kontekstu najvažnija od njih jest da se pitanja koja postavljam uglavnom bave značenjima koja kulturno i povijesno situirani pojedinci pridaju svijetu oko sebe, kako ta značenja nastaju i koje su njihove posljedice za svakodnevni život, ali i strukture društva. Teorijska perspektiva društvenog konstruktivizma, dakle, pružila je moje prvo teorijsko usmjerenje u području kolektivnih sjećanja i ona je izravno utjecala na moj pristup raznim postojećim konceptualizacijama kolektivnih sjećanja i na operacionalizaciju tog pojma u mom istraživanju.

\footnotetext{
${ }^{1}$ U Crottyjevoj interpretaciji (1998), pristupi interpretativizma ili društvenog konstruktivizma (unutar kojih se onda mogu razlikovati npr. simbolički interakcionizam, fenomenologija, hermeneutika itd.), pripadaju razini teorijske perspektive koja pak potpada pod epistemološku razinu konstrukcionizma. Teorijska perspektiva je teorijsko ili filozofsko polazište istraživanja koje informira odabir metodologije, dok je epistemologija teorijsko polazište na višoj razini apstraktnosti koja, polazeći od određenih pretpostavki o društvenom svijetu, razmatra kako ga je moguće spoznati (Crotty, 1998).
} 
Koncept kolektivnih sjećanja jest jedan od onih mnogoznačnih koncepata, poput kulture, kod kojeg postoje mnoga neslaganja i rasprave oko toga što zapravo označava. Tim raspravama pripomaže i interdisciplinarnost (ali često i interdisciplinarna nekomunikacija) koja obilježava ovo područje. Kolektivna sjećanja privlače interes mnogih disciplina, od sociologije, povijesti i antropologije pa do psihologije i književnih studija. U mnogim od tih pristupa kolektivna sjećanja su drukčije konceptualizirana. Štoviše, često se rabe i drukčiji termini. Osim kolektivnih sjećanja u jednini i množini (eng. collective memory/memories), u najčešćoj uporabi su i društvena sjećanja (eng. social memories), kulturna sjećanja (eng. cultural memories), javna sjećanja (eng. public memories) i kolektivna prisjećanja (eng. collective remembering) (Olick, 1999; Olick, Vinitzky-Seroussi i Levy, 2011; Erll, 2008; Hamilton i Shopes, 2008). K tome, na tragu razlikovanja njemačkih riječi Erinnerung i Gedächtnis, u hrvatskom se još pojavljuje i distinkcija između kolektivnog sjećanja i pamćenja (Brkljačić i Prlenda, 2006). U svim tim različitim pristupima najjasnije se osjeća dihotomija između dviju konceptualizacija kolektivnih sjećanja - tzv. individualističke i kolektivističke konceptualizacije (Olick, 1999).

Individualistička se konceptualizacija usmjerava na pojedince kao nosioce sjećanja (Halbwachs, 1992; Olick, 1999). Upravo pojedinci u svojim umovima aktualiziraju potencijalna kolektivna sjećanja pa tek usvajanjem i pridavanjem značenja od strane pojedinaca slike prošlosti dobivaju »uporabnu vrijednost« (Kansteiner, 2002). S druge strane, kolektivistička konceptualizacija kolektivnih sjećanja naglasak stavlja na utjelovljena ili opredmećena kolektivna sjećanja koja postoje neovisno o pojedinačnim umovima. Na taj način kolektivna sjećanja uglavnom promatraju tzv. semiotički pristupi kolektivnim sjećanjima (vidi npr. Assmann, 1995; Nora, 1996). Osim toga, kolektivističkoj konceptualizaciji kolektivnih sjećanja bliska je i skupina istraživača tzv. institucionalnog pristupa koji se uglavnom usredotočuju na oblikovanje kolektivnih sjećanja od strane političkih elita i medija (vidi npr. Schudson, 1992; Wagner-Pacifici i Schwartz, 1991). I kod semiotičkih i kod institucionalnih pristupa, kolektivna sjećanja su ponajprije javno dostupni simboli i diskursi poput komemoracijskih rituala, spomenika, kalendara, udžbenika i sličnih institucionaliziranih sjećanja (Halbwachs, 1992; Olick, 1999; Schwartz i Schuman, 2005). Upravo su semiotički i institucionalni pristupi, s kolektivističkom konceptualizacijom kolektivnih sjećanja, dominirali ovim područjem posljednjih dvadeset do trideset godina u kojima sociologija bilježi znatno povećanje interesa za sjećanja (Schwartz i Schuman, 2005). 
Iz prethodno spomenute razlike, očevidno je da je društvenokonstruktivistička teorijska perspektiva bliža individualističkim koncepcijama kolektivnih sjećanja. ${ }^{2}$ Naime, dok se autori koji koriste kolektivističke konceptualizacije uglavnom bave opredmećenim oblicima sjećanja i njihovim procesom institucionalizacije, autori koji kolektivna sjećanja konceptualiziraju individualistički usredotočuju se na značenja koja pojedinci pridaju narativima o prošlosti i razmatraju kako pojedinci kao aktivni akteri te narative tumače smješteni unutar svoga društvenog konteksta, što je onda bliskije istraživačima društvenokonstruktivističkog senzibiliteta. Stoga sam se u svom radu, vođena društvenokonstruktivističkom teorijskom perspektivom, usmjerila prema individualističkim konceptualizacijama kolektivnih sjećanja unatoč većoj zastupljenosti kolektivističkih konceptualizacija u mnogim publiciranim empirijskim istraživanjima u ovom području.

$\mathrm{Na}$ tom putu nisam bila ni prva ni sama. Upravo posljednjih godina sve veći broj znanstvenika naglašava kako je potrebno razmotriti ulogu pojedinca u studijama kolektivnih sjećanja (Crane, 1997; Confino, 1997; Kansteiner, 2002; Schwartz i Schuman, 2005). Mnogi autori također smatraju da je potrebno istraživanja o javno dostupnim ili institucionaliziranim sjećanjima nadopuniti istraživanjima njihove recepcije, čime se ponovno naglasak pomiče na pojedince kao nosioce sjećanja (Confino, 1997; Kansteiner, 2002; Wertsch, 2002; Schwartz i Schuman, 2005). No, unatoč tim teorijskim usmjerenjima, empirijskih je primjera koji individualistički pristup kolektivnim sjećanjima operacionaliziraju u praksi još uvijek relativno malo, ${ }^{3}$ barem u mainstream sociologiji. Jedan utjecajniji empirijski primjer takvog pristupa jest istraživanje Schwartza i Schumana (2005) u kojem autori uspoređuju prikaz Abrahama Lincolna u udžbenicima povijesti kroz godine sa stavovima o Lincolnu u anketama javnog mnijenja. Drugi, znatno brojniji primjeri su pak anketna istraživanja o generacijskim razlikama

\footnotetext{
${ }^{2}$ Iako treba napomenuti da i kolektivistička konceptualizacija također ima svoj konstruktivistički element. On je pogotovo izražen u pristupu tzv. politike sjećanja (eng. memory politics) koja ponajprije promatra strategije koje rabe političke elite kako bi naracije o prošlosti uskladile sa svojim interesima i potrebama (najpoznatiji primjer jest »izmišljanje tradicije« /Hobsbawm i Ranger, 1992/).

${ }^{3}$ Kao moguća iznimka, ovdje se može navesti tradicija usmene povijesti (eng. oral history), no jedan od razloga zašto je ovo područje ostalo izvan glavnih strujanja studija kolektivnih sjećanja jest upravo što se pojedinca i njegovu/njezinu životnu priču obično privilegira u tolikoj mjeri da iz tih analiza gotovo potpuno nestaje aspekt društvenih okvira, koji je ipak ključan u svakoj konceptualizaciji kolektivnih sjećanja (Olick, 1999; Hamilton i Shopes, 2008).
} 
u prisjećanju i znanju povijesnih događaja koja uglavnom rade Schuman i njegovi suradnici (Schuman i Scott, 1989; Schuman i Rieger, 1992; Jennings, 1996; Schuman i Corning, 2000; Schuman i Rodgers, 2004; Schuman i Corning, 2006). No, s obzirom na to da me je prema individualističkim konceptualizacijama kolektivnih sjećanja uputio interes o tome kako pojedinci konstruiraju značenja o prošlosti, ovi empirijski primjeri u kojima se pojedincima pristupalo uglavnom preko anketa doveli su do određenog nezadovoljstva. Naime, iako je u tim istraživanjima fokus prebačen s »vanjskih« opredmećenih sjećanja na pojedince koji ta sjećanja aktualiziraju u recepciji, anketni pristupi ipak ne dotiču dimenziju konstrukcije značenja o prošlosti. Činilo se nužnim, stoga, u mom istraživanju problemu kolektivnih sjećanja pristupiti iz rakursa kvalitativnih metoda čija je prednost upravo u mogućnosti dubinske analize konstrukcije značenja.

\section{Metodološki pristup i utemeljene istraživačke odluke}

\subsection{Istražuju li se društvenokonstruktivistička pitanja isključivo kvalitativnim metodama?}

Društvenokonstruktivistički ili interpretativistički pristup društvenim pitanjima ključno je utemeljen na radu Clifforda Geertza koji svojim zahtjevima »gustog opisa« (eng. thick description) naglašava proces tumačenja akterovih značenja iz njegove/njezine perspektive (Geertz, 1973). U današnjoj uporabi, društvenokonstruktivistička pitanja ponajprije se tiču složenosti i raznolikosti značenja koja pojedinci konstruiraju u međusobnoj interakciji i smješteni unutar specifičnoga kulturnog i povijesnog konteksta (Creswell, 2003). U tumačenjima nekih radikalnih društvenih konstruktivista ili kvalitativnih purista (Guba i Lincoln, 1985), društvenokonstruktivistička pitanja mogu se istraživati isključivo kvalitativnim metodama. Ti autori smatraju da je bilo koja druga kombinacija ontoloških i epistemoloških utemeljenja neprihvatljiva jer dovodi do kombinacije nesumjerljivih paradigmi (vidi $\mathrm{u}$ : Morgan, 2007; Greene, 2008). Nasuprot ovakvoj i sličnim pozicijama, drugo je stajalište da između društvenokonstruktivističke (ili interpretativističke) teorijske perspektive i kvalitativnih metoda postoji određeni afinitet, ali on ne uvjetuje njihovu nužnu spregu. Budući da društvenokonstruktivistička pitanja nastoje istražiti značenja koja akteri konstruiraju iz svoje perspektive, bez ograničenja unaprijed stvorenih istraživačevih kategorija (Creswell, 2003), kvalitativni su pristupi često najprimjereniji izbor metode. No, to ne znači da se pitanja iz perspektive društvenog konstruktivizma ne mogu primjereno istraživati i drugim metodama. 
Ova posljednja pozicija, koju slijedim u svom radu, temelji se na diferenciranju hijerarhijskih razina epistemologije i teorijske perspektive (Crotty, 1998; Morgan, 2007). Crotty (1998) tako smatra da je interpretativizam (društveni konstruktivizam u mojoj terminologiji) teorijska perspektiva, odnosno način gledanja na svijet koji pretpostavlja kulturnu i društvenu situiranost tumačenja o značenjima koje pojedinci stvaraju o svijetu u kojem žive. Konstrukcionizam, s druge strane, jest epistemološka pozicija koja polazi od pretpostavke o nemogućnosti tzv. objektivnog znanja ili »istine« koja postoji neovisno o pojedincima budući da se sva značenja konstruiraju kroz interakciju pojedinaca sa svijetom u kojem žive. Interpretativizam (društveni konstruktivizam) jest jedna od teorijskih perspektiva proizišlih iz epistemološke pozicije konstrukcionizma, gdje je ovo posljednje viša hijerarhijska razina filozofskih pretpostavki o tome kakva je vrsta znanja moguća i koja je usko vezana uz ontološke pretpostavke o naravi društvenog svijeta. Crotty dalje posebice naglašava kako epistemološka pozicija konstrukcionizma nije subjektivistička pozicija budući da se značenja niti otkrivaju niti ih subjekt/akter nameće objektu/društvenom svijetu, nego ih akteri konstruiraju kroz svoju smještenost $u$ društvenom svijetu: »... interpretacija kao stvaranje značenja ne osuđuje nas na subjektivizam niti nas osuđuje na individualizam. Mi moramo u obzir uzeti društveno podrijetlo značenja i društvenu narav kojom je ono nužno označeno« (Crotty, 1998: 52).

Upravo ovdje Crotty identificira glavni problem radikalnih društvenih konstruktivista i njihove pozicije o nesumjerljivosti paradigmi. Po njegovom mišljenju, ti autori zapravo kreću iz epistemološke pozicije subjektivizma u kojoj značenja ne nastaju iz međusobnog odnosa subjekta i objekta, nego ih subjekt/akter nameće objektu/društvenom svijetu, iz čega onda proizlazi da je subjektivne svjetove značenja koja nastaju na taj način moguće istraživati samo preko kvalitativnih metoda. S druge strane, epistemološka pozicija konstrukcionizma, kao i teorijske perspektive interpretativizma (društvenog konstruktivizma) koja proizlazi iz nje, ne smatra da je »objektivno« znanje moguće, ali nadilazi dihotomiju objektivno - subjektivno te stoga njezino vezivanje samo uz određenu skupinu metoda nema smisla.

\subsection{Posljedice odbacivanja načela o nesumjerljivosti paradigmi $i$ ishodišni položaj istraživačkog problema}

Odbacivanje načela o nesumjerljivosti paradigmi, doduše, ne znači da »sve ide«. Iz moje perspektive, to samo znači da nijedan korak na putu od teorije preko metode do analize rezultata ne proizlazi nužno iz prethodnoga, 
nego svaki od tih koraka treba osvijestiti i utemeljiti. Slično poziciji metodološkog pragmatizma u eksplikaciji autora koji se uglavnom bave kombiniranim ili mješovitim metodama, ključna točka oko koje se vrti svaka odluka jest istraživački problem (Johnson i Onwuegbuzie, 2004; Biesta, 2010; Feilzer, 2010). Pri traženju najprimjerenijih metoda odgovora na istraživačka pitanja, istraživači imaju punu slobodu izbora metoda, tehnika i procedura istraživanja koje najbolje odgovaraju njihovim potrebama i svrhama (Creswell, 2003: 12-13). Ono što je ključno jest da je izabrani put od istraživačkog problema do načina na koji mu se pristupa svrhovit i da uspješno propituje one dimenzije tog problema koje su istraživaču od interesa (Morgan, 2007). Dakle, zadatak je istraživača jasno eksplicirati poveznicu svojih teorijskih postavki i istraživačkih odluka te pokazati da su njegovi/njezini metodološki izbori uistinu svrhoviti i primjereni za problem koji propituje.

\subsection{Od istraživačkog problema do metode i utemeljenih istraživačkih odluka}

Iz ove sam pozicije pristupila i svom istraživanju, što je značilo da su, nakon definiranja istraživačkog problema, sve daljnje odluke - uključivši i moguće modifikacije ili nadopunjavanja izabrane metode - bile vođene konkretnim teorijskim pitanjima. Prvo pitanje koje se iskristaliziralo kroz pregled literature bilo je pitanje o tome kako kolektivna sjećanja nastaju. Ovdje me je ponajprije zanimalo kako društvena smještenost pojedinca i raznoliki mogući utjecaji (od obitelji i drugih skupina pa do makroutjecaja medija i političkih ideologija) zajedno oblikuju način na koji pojedinac tumači dostupne narative o prošlosti i konačno prihvaća jedan od njih kao svoj osobni narativ. Na to se pitanje nadovezalo i pitanje o tome kako se kolektivna sjećanja prenose novim generacijama. Naime, upravo se kroz identificiranje najvažnijih linija utjecaja na narative pojedinca onda može prići i mogućim utjecajima na nove generacije, a kroz to, i na društvenu reprodukciju određenih perspektiva o prošlosti. Na ova sam pitanja pokušala odgovoriti kroz istraživanje formiranja kolektivnih sjećanja o komunističkoj Jugoslaviji kod dviju mladih hrvatskih poslijejugoslavenskih generacija.

Time dolazimo do ključne točke kod oblikovanja nacrta istraživanja u kojoj je trebalo prijeći jaz između teorijskih pozicija i konkretnih istraživačkih odluka. Prva je odluka bila vezana uz operacionalizaciju kolektivnih sjećanja. Slijedeći individualističku konceptualizaciju kolektivnih sjećanja, 
moje istraživanje stavlja pojedinca u središte te kolektivna sjećanja operacionalizira kao osobne narative ili percepcije pojedinaca o jugoslavenskoj prošlosti. Budući da se istraživanjem žele identificirati značenja koja akteri smješteni u određenom sociokulturnom kontekstu pripisuju prošlosti, intervju je izabran kao primjerena metoda odgovora na ovakva pitanja. Prije svega, intervjui dopuštaju izražavanje osobnih perspektiva aktera koje je u manjoj mjeri ograničeno istraživačevima postojećim koncepcijama. Alternativne metode kojima bi se također moglo doći do osobnih perspektiva, poput anketnog upitnika ili fokusnih skupina, bile bi manje primjerene zbog sljedećih razloga. Ponajprije, anketni upitnici bi mogli procjenjivati samo ispitanikovo (ne)prihvaćanje unaprijed stvorenih kategorija te bi se tako izgubila ispitanikova perspektiva i vlastito tumačenje te perspektive. Potom, fokusne bi skupine unijele dodatni faktor utjecaja grupne dinamike pri iznošenju priča o jugoslavenskoj prošlosti, čime bi se otežalo razmatranje akterovih osobnih gledišta i percipiranih utjecaja na ta gledišta. Osim toga, u skladu s perspektivom o sociokulturnoj utemeljenosti subjektivnosti, ${ }^{4}$ dubinski intervjui ne predmnijevaju razdvajanje akterovih perspektiva/diskursa od sociokulturnog konteksta u kojem su formirani.

Jedna od dodatnih prednosti intervjua bilo je i to što je omogućio da svoje ispitanike pitam o izvoru različitih narativa o Jugoslaviji (npr. jesu li nešto čuli od roditelja ili u školi ili na televiziji) kao i o njihovoj evaluaciji legitimnosti različitih izvora (npr. ako su se roditeljske i udžbeničke priče razlikovale, kome su oni više vjerovali). Dakako, kad se u obzir uzme dobro poznata pogrešivost sjećanja (eng. fallibility of memory), jasno je da se ne može očekivati od ispitanika da će uvijek moći identificirati takve izvore ili da će ih uvijek ili čak većinom ispravno identificirati. No, otkrivanje neke »skrivene« ili jedine »autentične istine« niti je svrha ovog istraživanja, niti je nešto što smatram mogućim. Jedino što ovdje intervjui mogu pružiti - a što i jest ono što se od njih očekuje - jesu percipirani izvori narativa o prošlosti, a time donekle i percepcija postojećega javnog diskursa o Jugoslaviji i drugih izvora priča o prošlosti.

Dalje, iako je istraživanje recepcije kolektivnih sjećanja preko intervjua bila dimenzija koja mi se činila bitnom i nedostatno zastupljenom u

\footnotetext{
${ }^{4}$ Vidi npr. naglaske na sociokulturnoj utemeljenosti subjektivnosti koji se mogu iščitati iz poststrukturalističke/postmoderne teorije i razvoja kritične diskurzivne analize, kao i sociokulturnog zaokreta u psihologiji (Agger, 1991; Blommaert i Bulcaen, 2000; Kirschner, 2010).
} 
mainstream literaturi o kolektivnim sjećanjima, takvo istraživanje ipak nije u potpunosti odgovaralo na postavljena istraživačka pitanja. Nedostajao je aspekt smještenosti u širi društveni kontekst u kojem akteri pregovaraju dostupne narative o prošlosti koji bi mi omogućio da procijenim međusobno djelovanje i eventualnu uspješnost različitih mogućih utjecaja na osobne narative pojedinaca (javni diskurs, mediji, škola, lokalna zajednica, obitelj...). Kako bih obuhvatila i taj aspekt, činilo mi se potrebnim usporediti javni kontekst sjećanja u Jugoslaviji (odnosno dominantni diskurs o Jugoslaviji političkih elita i medija) s percepcijom tog konteksta od strane mojih ispitanika.

Posljedica ove odluke bila je nadopunjavanje dimenzije recepcije kolektivnih sjećanja dimenzijom proizvodnje sjećanja. Drugim riječima, osim intervjua, u nacrt istraživanja dodana je tekstualna (kvalitativna) analiza dominantnih prikaza Jugoslavije u udžbenicima povijesti i novinama kao indikatorima javnog diskursa o Jugoslaviji. Naime, usporedba »stvarnog« i percipiranoga javnog diskursa i mogućih alternativnih izvora slika o prošlosti jedini je način kojim se mogu identificirati značajna izostavljanja ili pak drukčiji naglasci u prikazu Jugoslavije »odozgo« (u proizvodnji kolektivnih sjećanja) i »odozdo« (u njihovoj recepciji i tumačenju). U konačnici, nacrt mog istraživanja o kolektivnim sjećanjima temeljio se na dvama glavnim elementima: 1) dubinskim intervjuima koji su nastojali identificirati glavne narative/perspektive o jugoslavenskoj prošlosti i glavne percipirane izvore tih narativa/perspektiva; 2) tekstualnoj analizi prikaza Jugoslavije u udžbenicima povijesti i novinama u poslijejugoslavenskom razdoblju koje je činilo društveni kontekst u kojem su moji ispitanici formirali sjećanja o Jugoslaviji.

\subsection{Pitanja valjanosti, pouzdanosti i poopćivosti}

Utemeljene istraživačke odluke bi se, osim iz perspektive primjerenosti za odgovaranje na postavljena istraživačka pitanja, također trebale razmotriti iz perspektive valjanosti (eng. validity), pouzdanosti (eng. reliability) i poopćivosti (eng. generalizibility) $)^{5}$ metode, podataka, zaključaka i tumačenja (za argumentaciju zbog čega je potrebno procjenjivati ove kriterije pri evaluaciji rezultata kvalitativnog istraživanja vidi: Vučković Juroš, 2011). Fokus ovog rada nije na ovim pitanjima, no osvrnut ću se ukratko na pita-

\footnotetext{
${ }^{5}$ Iako preuzeti iz vokabulara kvantitativnih metoda, ovi koncepti su za potrebe kvalitativnih metoda prilagođeni njihovim specifičnostima (vidi Hammersley, 1992; Gobo, 2008).
} 
nja valjanosti koja su bila izravno vezana uz primjerenost donesenih istraživačkih odluka, kao i na pitanja poopćivosti kao glavne »boljke« kojom se najčešće ograničavaju teorijski potencijali kvalitativnih istraživanja.

Prvo pitanje valjanosti odnosi se na primjerenost povijesnih udžbenika i novina kao indikatora javnog diskursa o Jugoslaviji. Ovaj se izbor temelji na sljedećim razlozima. Najprije, obrazovni sustav pruža jedinstven i autoritativan okvir unutar kojeg se određeni prikaz prošlosti sustavno distribuira svim skupinama u društvu. Budući da je obrazovni sustav privilegirana domena državne regulacije (Apple, 2000, 2003), mnogi autori analiziraju upravo povijesno obrazovanje kako bi identificirali nacionalne perspektive o prošlosti (Dierkes, 2010). U hrvatskom slučaju, primjerenost udžbenika povijesti kao indikatora diskursa o prošlosti političkih elita dodatno je utemeljena na specifičnom društvenom i institucionalnom kontekstu devedesetih koje odlikuje strogo centralizirani sustav u kojem je kontrola nad kurikulumom povijesti i udžbenicima povijesti bila u rukama ljudi bliskih vladajućem HDZ-u i predsjedniku Tuđmanu (Najbar-Agičić i Agičić, 2007). Dakle, za očekivati je bilo da će se u udžbenicima povijesti naći najsustavnija »službena« formulacija perspektiva o Jugoslaviji. Dalje, izbor novina umjesto, npr. televizije ili drugih medija kao indikatora medijskog diskursa o Jugoslaviji temelji se na praktičnim i teorijskim razlozima. Praktični razlozi su relativna nedostupnost ostalih medijskih materijala, što onemogućuju njihovu sustavnu analizu, a teorijski se razlozi temelje na monopolističkoj poziciji državne televizije u devedesetima - koja je, opet, bila pod kontrolom HDZ-a (Malović i Selnow, 2001). Ovo smanjuje vjerojatnost će se npr. u televizijskom materijalu naći narativi koji odstupaju od »službenih« narativa koji se očekuju naći u povijesnim udžbenicima.

Drugo pitanje valjanosti tiče se odluke o generacijskom definiranju ispitanika, odnosno uključivanju jedino dvije mlade generacije - jedne rođene 1978. - 1981. i druge rođene 1989. - 1991. godine. Ova je odluka bila izravno vezana uz drugo istraživačko pitanje o tome kako se perspektive o prošlosti prenose novim generacijama u društvu. Ove dvije generacije razlikovale su se u malim specifičnostima društvenog konteksta (npr. osobno iskustvo Jugoslavije u ranom djetinjstvu nasuprot nikakvog iskustva Jugoslavije iz čega su npr. proizišla i različita iskustva obrazovnog sustava i javnog diskursa u formativnim godinama). Istodobno, posrijedi su generacije kojima su glavne perspektive o Jugoslaviji morale biti prenesene preko sekundarnih izvora. Ovakvo generacijsko utemeljenje ispitanika nije 
omogućilo samo uvid u proces prenošenja kolektivnih sjećanja novim generacijama, nego je također omogućilo i bolji pregled toga kako akteri prihvaćaju i evaluiraju narative o Jugoslaviji koji su dostupni preko raznolikih sekundarnih izvora (škola, mediji, roditelji...) kad su ti sekundarni izvori jedini način na koji se formiraju osobni narativi o jugoslavenskoj prošlosti.

Konačno, u pitanju poopćivosti, kao što je uobičajeno u kvalitativnim istraživanjima, ni ovo se istraživanje ne temelji na slučajnom reprezentativnom uzorku. Dakle, ne možemo govoriti o probabilističkoj poopćivosti koja bi omogućila zaključivanje o cijeloj populaciji iz koje je uzorak izveden. Iako to svakako jest ograničenje kvalitativnih istraživanja, unutar kvalitativnoga se metodološkog okvira, umjesto toga, naglasak premješta na razmatranje teorijski utemeljene poopćivosti koja, unutar granica provedenog istraživanja, omogućuje razmatranje njegovih teorijskih potencijala (Gobo, 2008). Glavni dio ovog istraživanja kolektivnih sjećanja temelji se na dubinskim intervjuima s pripadnicima dviju hrvatskih poslijejugoslavenskih generacija. ${ }^{6}$ Uzorkovanje se temeljilo na načelu maksimalne varijacije (Lindlof i Taylor, 2002) kojem je svrha bila prikupiti što raznovrsnije narative o Jugoslaviji. Kako bi se to postiglo, ispitanici su regrutirani na temelju generacijskog pripadništva, obrazovanja i regionalne pripadnosti. U konačnici, 72 ispitanika prikupljenih osobnim kontaktima i metodom »grude snijega« činili su uistinu raznovrsnu skupinu mladih ljudi iz različitih dijelova Hrvatske i različitih profesionalnih i obrazovnih profila zbog čega mi se čini da sam uspješno prikupila širok raspon perspektiva o Jugoslaviji, pogotovo što je, u kvalitativnim okvirima, riječ o relativno velikom uzorku.

Dakako, mogući problem ovakvog uzorkovanja jest pitanje samoselekcije. Moguće je da su samo oni mladi ljudi koji su bili posebno zainteresirani za temu Jugoslavije ili oni koji su bili skloniji pozitivnije razmatrati jugoslavensku prošlosti također bili skloniji javiti se za sudjelovanje u istraživanju. To ograničenje treba svakako imati na umu pri razmatranju mojih tumačenja, ali bih također istaknula da se među ispitanicima našla i nekolicina mladih ljudi koji su vrlo jasno izrazili svoju nezainteresiranost, pa i neznanje o toj temi, te koji su na sudjelovanje u istraživanju pristali kao uslugu osobama koje su me povezale s njima. Stoga smatram da je istraži-

\footnotetext{
${ }^{6}$ Poopćivost povijesnih udžbenika i novina manje je upitna. Kod udžbenika, u istraživanje je uključena cijela populacija povijesnih udžbenika (sva prva izdanja i kasnija izdanja ako su modificirana) objavljenih u relevantnom razdoblju. Novine su pak predstavljene preko četiri lista, Večernjeg lista i Vjesnika te Novog lista i Feral Tribunea, za koje je uvriježeno da je riječ o glavnim mainstream i opozicijskim listovima devedesetih.
} 
vanje uistinu prikupilo raznovrsne moguće perspektive o Jugoslaviji među dvjema mladim hrvatskim generacijama. Takav strateški izbor ispitanika (Flyvbjerg, 2004) omogućuje mi pretpostavku da će perspektive koje nije spomenuo nijedan od mojih ispitanika uistinu biti rijetke u populaciji ovih dviju generacija. $\mathrm{K}$ tome, uočeni obrasci narativa o Jugoslaviji s obzirom na sličnosti i razlike među ispitanicima također će biti vrijedne daljnjega teorijskog razmatranja o dinamici formuliranja kolektivnih sjećanja. Uočavanje takvih obrazaca bilo bi teško moguće iz drukčijih istraživačkih nacrta.

\section{Doprinos razumijevanju kolektivnih sjećanja: od teorije do teorije}

Konačno, u ovoj posljednjoj sekciji dolazim do najvažnijeg i najtežeg zadatka svakog istraživanja, a to je daljnji doprinos razumijevanju teorijskih problema, bilo za specifično područje kojim se istraživanje bavi, bilo za šire društvene obrasce. Glavno pitanje koje se mora postaviti na kraju jest kako specifičan kvalitativan pristup ovog istraživanja kolektivnih sjećanja dalje pridonosi ovom području i sociološkoj teoriji? No, prije nego što dublje izložim doprinose ovog istraživanja, željela bih također ukazati na zamku argumentacije »bez kvalitativnog istraživanja ovo ne bismo vidjeli«. Naime, čini mi se da se kvalitativni istraživači često ograničuju upravo ovakvim okvirom iznošenja doprinosa vlastitog istraživanja. Iako novi pogled kvalitativnog pristupa uvijek jest zanimljiv i vrijedan, smatram da $\mathrm{u}$ razmatranju teorijskih implikacija svakog istraživanja (ne samo kvalitativnog) treba pokušati krenuti i korak dalje. Nešto što još nismo vidjeli iz neke perspektive jest bitno, ali pravo pitanje nije »što još nismo vidjeli«, nego »zašto bismo to uopće trebali vidjeti«. Pokušat ću stoga u izlaganju glavnih doprinosa ovog istraživanja također napraviti taj daljnji korak.

$\mathrm{Na}$ ovom bih mjestu naglasila dva glavna doprinosa ovog istraživanja. Jedan proizlazi iz metodološke kombinacije tekstualne analize povijesnih udžbenika i novina i dubinskih intervjua, a drugi se temelji na nalazima koje je bilo moguće dobiti samo intervjuima. Metodološka kombinacija tekstualne analize i intervjua omogućila je usporedbu proizvodnje i recepcije sjećanja te je tako izbjegla jednu od slabosti trenutačno dominantnih institucionalnih i semiotičkih pristupa kolektivnim sjećanjima koji se usredotočuju samo na proizvodnju sjećanja »odozgo«, od strane političkih elita i medija. No, dominacija takvog pogleda »odozgo« i zanemarivanje pitanja recepcije kolektivnih sjećanja jest problematično jer nosi opasnost pretpo- 
stavke da će "publika« pasivno prihvatiti sva značenja i poruke koje su stvorili političke elite i mediji. Slijedeći M. Archer, Kansteiner (2002) naziva ovu pretpostavku »spajanje prema dolje« (eng. downward conflation). Drugim riječima, ovakvi pristupi često impliciraju da je za identifikaciju kolektivnih sjećanja nekog društva dovoljno identificirati kolektivna sjećanja koja dominiraju javnim diskursom. Iako takva situacija općeprihvaćenoga društvenog konsenzusa zaista u nekim društvima i o nekim pitanjima može biti slučaj, ona ipak ne može biti implicitna pretpostavka razmatranja kolektivnih sjećanja.

Rezultati mog istraživanja o kolektivnim sjećanjima na komunističku Jugoslaviju potvrđuju neodrživost pretpostavke da su kolektivna sjećanja koja dominiraju javnim diskursom nužno dominantna kolektivna sjećanja tog društva. Naime, da se moje istraživanje ograničilo samo na kolektivna sjećanja koja su u 1990-ima i 2000-tima bila dominantna u povijesnim udžbenicima i novinama, došla bih do zaključka da u hrvatskom društvu prevladavaju ponajprije negativne reevaluacije Jugoslavije u kojima se ona promatra uglavnom kroz okvir etničkog ugnjetavanja Hrvatske, političke represije, nedemokracije i neuspješne socijalističke ekonomije. No, intervjui su pokazali da među mladim Hrvatima zapravo prevladava perspektiva dobrog života u Jugoslaviji u kojoj su se stvari lakše i bolje rješavale za »male ljude«. Takva je perspektiva vrlo »glasno« odsutna iz javnog diskursa o Jugoslaviji, a nesumnjivo dominira kod velike većine mladih u mom uzorku, bez obzira na njihove međusobne razlike. Zašto je to bitno? Osim što, dakako, ima značaj za bolje razumijevanje problema koji trenutačno muče hrvatsko društvo (npr. problema legitimacije određenih socijalnih politika), ovaj je nalaz bitan za područje kolektivnih sjećanja jer pokazuje da iako institucionalizirana sjećanja (primjerice, narativi povijesnih udžbenika) nesumnjivo utječu na naglašavanje određenih perspektiva o prošlosti u javnom diskursu, ti narativi »odozgo« nisu jedini izvori kolektivnih sjećanja pojedinaca, nego se moraju natjecati s alternativnim izvorima.

Nadalje se postavlja pitanje u kojim se slučajevima pojavljuje otpor narativima »odozgo« i kada ti alternativni izvori perspektiva o prošlosti postaju legitiman i bitan izvor utjecaja na akterove narative o prošlosti. Upravo se u odgovoru na ovo pitanje pokazuje neovisan i specifičan doprinos dubinskih intervjua. Naime, intervjui s mladim hrvatskim generacijama omogućili su pitanja o »izvorima« različitih perspektiva o Jugoslaviji i njihovu evaluaciju. Ti su rezultati pokazali da se među ispitanicima izdvoji- 
la skupina mladih ljudi sa strukovnim obrazovanjem kao skupina čija se perspektiva o Jugoslaviji svodila gotovo isključivo na perspektivu»boljeg života«, dok se ostali aspekti gotovo nisu spominjali. Ta je dominantna perspektiva proizlazila iz većeg oslanjanja ove skupine na priče njihovih roditelja (i ostalih starijih ljudi) nasuprot ostalim mogućim izvorima narativa o Jugoslaviji (poput medija ili škole koja je, usput rečeno, u hrvatskom kontekstu obilježena sustavnim zanemarivanjem povijesnog obrazovanja mladih ljudi u strukovnim školama). S druge strane, obrazovaniji ispitanici bili su skloniji korištenju više izvora perspektiva o prošlosti i shodno tomu, njihove su perspektive o prošlosti često bile raznovrsnije, a nerijetko su uključivale i kritičniju evaluaciju nekih od svojih izvora (npr. roditelja ili medija).

Ovi su nalazi bitni za područje kolektivnih sjećanja jer upućuju na važnu dinamiku u procesu prihvaćanja i prenošenja kolektivnih sjećanja. Ponajprije, bliski usmeni izvori narativa o prošlosti (poput roditelja ili starijih članova obitelji i poznanika) imaju znatan utjecaj na kolektivna sjećanja mladih ljudi slabijeg obrazovanja (u ovom slučaju, strukovnog obrazovanja) budući da ta populacija ima ograničen pristup povijesnim činjenicama i kompleksnijim historijskim tumačenjima. U takvom će kontekstu ti mladi ljudi lakše nekritički prihvatiti jedine istinski dostupne perspektive o prošlosti - one njihovih roditelja i ljudi koji ih okružuju. S druge strane, bolje obrazovani ispitanici često će imati bolje razumijevanje povijesnih kompleksnosti što otežava njihovo nekritičko prihvaćanje roditeljskih perspektiva ( $k a d$ se one razlikuju od perspektiva, primjerice, škole), ali te će alternativne perspektive također biti važni izvori propitivanja i mogućeg otpora narativa »odozgo«. Dakle, institucionalni ili izvori narativa o prošlosti »odozgo« (a to su izvori kojima se ponajprije bave dominantni semiotički i institucionalni pristupi kolektivnim sjećanjima) imaju ozbiljnu konkurenciju tzv. usmenih izvora (primjerice roditelja) koji pak postaju ključni u situaciji neuspješnog ${ }^{7}$ ili manjkavoga povijesnog obrazovanja ${ }^{8}$ čime usmeni izvori za određene skupine u društvu postaju jedini značajni izvori narativa o prošlosti.

\footnotetext{
${ }^{7}$ Ovo bi, primjerice, uključilo i ideološko obrazovanje (npr. u totalitarnim ili autoritarnim sustavima) koje zbog svojega očitog ideološkog utemeljenja gubi dio legitimnosti.

${ }^{8}$ To može biti posljedica neuspješnog ili manjkavoga povijesnog obrazovanja unutar »službenoga« obrazovanog sustava, ali i posljedica vlastite nezainteresiranosti za historijska znanja i razumijevanja.
} 
Ova dva nalaza, o neodrživosti spajanja institucionaliziranih kolektivnih sjećanja $\mathrm{i}$ njihove recepcije te o dinamici utjecaja različitih izvora na individualne narative o prošlosti, upućuju na specifičan doprinos kvalitativne metode boljem razumijevanju kolektivnih sjećanja. Ne samo da bez uporabe kvalitativnih metoda pogled na ovu dimenziju problema ne bi bio moguć, nego bi i šire razumijevanje procesa nastanka i prenošenja kolektivnih sjećanja u društvu bilo manjkavo. Ovime sam pokazala kako je kvalitativan pristup omogućio jedan teorijski doprinos problemu recepcije i formiranja kolektivnih sjećanja kakav dominantni semiotički i institucionalni pristupi nisu mogli pružiti.

\section{Zaključak}

U ovom sam radu prikazala proces međusobnog nadopunjavanja teorije $\mathrm{i}$ istraživačkih odluka koji se dogodio »iza pozornice« jednog istraživanja kolektivnih sjećanja. U tom procesu prikazala sam kako je pozicioniranje unutar teorijske perspektive društvenog konstruktivizma usmjerilo moja promišljanja kolektivnih sjećanja. U skladu s konstruktivističkim naglaskom na značenja koja akteri stvaraju, u ovom sam istraživanju prihvatila individualističku konceptualizaciju kolektivnih sjećanja koja ponajprije promatra pojedince kao nosioce i aktere prihvaćanja i tumačenja dostupnih narativa o prošlosti. Unutar te perspektive dalje sam formulirala uža istraživačka pitanja ovog istraživanja koja su, propitujući proces nastanka i prenošenja kolektivnih sjećanja, ponovno naglašavala položaj i perspektivu pojedinca. Dalje sam prikazala kako su me istraživačka pitanja usmjerila prema kvalitativnim metodama koja su pružala rakurs koji sam ocijenila nedostatno zastupljenim u dominantnim pristupima u području kolektivnih sjećanja te kako sam na svoja pitanja pokušala odgovoriti služeći se dubinskim intervjuima s dvije mlade hrvatske generacije i tekstualnom analizom udžbenika povijesti i novina. Osim na valjanost tih metoda pri odgovoru na istraživačka pitanja o nastanku i prenošenju kolektivnih sjećanja kao osobnih narativa ili perspektiva o prošlosti, također sam se osvrnula i na pitanje teorijske poopćivosti rezultata ovog istraživanja koja su bitna pri razmatranju njegovih teorijskih potencijala. Konačno, u posljednjoj sam sekciji nastojala pokazati specifičan doprinos ovoga kvalitativnog pristupa području kolektivnih sjećanja, pri čemu pozornost nisam pokušala usmjeriti samo na doprinos nove perspektive koju ovaj pristup pruža u odnosu na ostale pristupe kolektivnim sjećanjima, nego i odgovoriti na pitanje zbog čega je ovakva perspektiva bitna u širim razmjerima. 
Ovakvim ekspliciranjem utemeljenja i doprinosa vlastitog istraživanja teorijskom području unutar kojeg se smješta, cilj ovog rada bio je prikazati jedan od mogućih modela kojima kvalitativni, ali i kvantitativni istraživači, mogu pridonijeti transparentnosti svojega istraživačkog procesa. U konačnici, takva predanost kontinuiranom promišljanju teorijskih utemeljenja istraživačkih odluka i razmatranju teorijskih implikacija tako dobivenih nalaza, može samo povećati povjerenje prema ishodima socioloških istraživanja, bez obzira na to kojom su metodom provedeni, i tako povećati značaj i relevantnost ove profesije.

\section{LITERATURA}

Agger, Ben (1991). »Critical Theory, Poststructuralism, Postmodernism: Their Sociological Relevance«, Annual Review of Sociology, 17: 105-131. doi:10.2307/2083337

Apple, Michael W. (2000). Official Knowledge: Democratic Education in a Conservative Age. New York i London: Routledge.

Apple, Michael W. (2003). The State and the Politics of Knowledge. New York i London: Routledge.

Assmann, Jan (1995). »Collective Memory and Cultural Identity«, New German Critique, (65): 125-133. doi:10.2307/488538

Biesta, Gert (2010). »Pragmatism and the Philosophical Foundations of Mixed Methods Research«, u: Abbas Tashakkori i Charles Teddlie (ur.). Sage Handbook of Mixed Methods in Social and Behavioural Research. 2nd ed. London: Sage, str. 95-117.

Blommaert, Jan i Bulcaen, Chris (2000). »Critical Discourse Analysis«, Annual Review of Anthropology, 29: 447-466. doi:10.2307/223428

Brkljačić, Maja i Prlenda, Sandra (2006). »Zašto pamćenje i sjećanje?«, u: Maja Brkljačić i Sandra Prlenda (ur.). Kultura pamćenja i historija. Zagreb: Golden marketing - Tehnička knjiga, str. 7-18.

Confino, Alon (1997). »Collective Memory and Cultural History: Problems of Method«, The American Historical Review, 102 (5): 1386-1403. doi:10.2307/2171069

Crane, Susan A. (1997). »Writing the Individual Back into Collective Memory«, The American Historical Review, 102 (5): 1372-1385. doi:10.2307/2171068

Creswell, John W. (2003). Research Design: Qualitative, Quantitative, and Mixed Methods Approaches. 2nd ed. London: Sage.

Crotty, Michael (1998). The Foundations of Social Research: Meaning and Perspective in the Research Process. London: Sage.

Dierkes, Julian (2010). Postwar History Education in Japan and the Germanys: Guilty Lessons. New York: Routledge.

Erll, Astrid (2008). »Cultural Memory Studies: An Introduction«, u: Astrid Erll, Ansgar Nünning i Sara B. Young (ur.). Cultural Memory Studies: An International and Interdisciplinary Handbook. Berlin i New York: De Gruyter, str. $1-15$. 
Feilzer, Martina Yvonne (2010). „Doing Mixed Methods Research Pragmatically: Implications for the Rediscovery of Pragmatism as a Research Paradigm «, Journal of Mixed Methods Research, 4 (1): 6-16. doi:10.1177/1558689809349691 Flyvbjerg, Bent (2004). »Five Misunderstandings about Case-Study Research«, u: Clive Seale, Giampietro Gobo, Jaber F. Gubrium i David Silverman (ur.). Qualitative Research Practice. London: Sage, str. 420-434. doi:10.4135/9781848608191. d33

Geertz, Clifford (1973). The Interpretation of Cultures. New York: Basic Books.

Gobo, Giampietro (2008). »Re-Conceptualizing Generalization: Old Issues in a New Frame«, u: Pertti Alasuutari, Leonard Bickman i Julia Brannen (ur.). The SAGE Handbook of Social Research Methods. London: Sage, str. 193-213. doi:10.4135/9781446212165.n12

Goffman, Erving (1956). The Presentation of Self in Everyday Life. Edinburgh: University of Edinburgh.

Greene, Jennifer C. (2008). »Is Mixed Methods Social Inquiry a Distinctive Methodology?«, Journal of Mixed Methods Research, 2 (1): 7-22. doi:10.1177/1558689807309969

Guba, Egon G. i Lincoln, Yvonna S. (1985). Naturalistic Inquiry. New York: Sage. Halbwachs, Maurice (1992 [1952]). On Collective Memory. Chicago: University of Chicago Press.

Hamilton, Paula i Shopes, Linda (2008). »Introduction: Building Partnerships between Oral History and Memory Studies«, u: Paula Hamilton i Linda Shopes (ur.). Oral History and Public Memories. Philadelphia: Temple University Press, str. vii-xvii.

Hammersley, Martyn (1992). What's Wrong with Ethnography? Methodological Explorations. London i New York: Routledge.

Hobsbawm, Eric J. i Ranger, Terence O. (1992). The Invention of Tradition. Cambridge: Cambridge University Press.

Jennings, M. Kent (1996). »Political Knowledge Over Time and Across Generations«, Public Opinion Quarterly, 60 (2): 228-252. doi:10.1086/297749

Johnson, R. Burke i Onwuegbuzie, Anthony J. (2004). »Mixed Methods Research: A Research Paradigm Whose Time Has Come «, Educational Researcher, 33 (7): 14-26. doi:10.3102/0013189x033007014

Kansteiner, Wolf (2002). »Finding Meaning in Memory: A Methodological Critique of Collective Memory Studies«, History and Theory, 41 (2): 179-197. doi:10.1111/0018-2656.00198

Kirschner, Suzanne R. (2010). »Sociocultural Subjectivities: Progress, Prospects, Problems«, Theory \& Psychology, 20 (6): 765-780. doi:10.1177/0959354310375745

Lindlof, Thomas R. i Taylor, Bryan C. (2002). Qualitative Communication Research Methods. London: Sage.

Malović, Stjepan i Selnow, Gary W. (2001). The People, Press, and Politics of Croatia. London: Praeger Publishers.

Morgan, David L. (2007). »Paradigms Lost and Pragmatism Regained: Methodological Implications of Combining Qualitative and Quantitative Methods «, Journal of Mixed Methods Research, 1 (1): 48-76. doi:10.1177/2345678906292462 
Najbar-Agičić, Magdalena i Agičić, Damir (2007). »The Use and Misuse of History Teaching in 1990s Croatia«, u: Sabrina P. Ramet i Davorka Matić (ur.). Democratic Transition in Croatia: Value Transformation, Education, and Media. College Station, Texas: Texas A\&M University Press, str. 193-223.

Nora, Pierre (1996). »General Introduction: Between Memory and History«, u: Pierre Nora (ur.). Realms of Memory: Rethinking the French Past. New York: Columbia University Pess, str. 1-20.

Olick, Jeffrey K. (1999). »Collective Memory: The Two Cultures«, Sociological Theory, 17 (3): 333-348. doi:10.2307/370189

Olick, Jeffrey K., Vinitzky-Seroussi, Vered i Levy, Daniel (2011). »Introduction«, u: Jeffrey K. Olick, Vered Vinitzky-Seroussi i Daniel Levy (ur.). The Collective Memory Reader. Oxford: Oxford University Press, str. 3-62.

Schudson, Michael (1992). Watergate in American Memory: How We Remember, Forget, and Reconstruct the Past. New York: Basic Books.

Schuman, Howard i Corning, Amy D. (2000). »Collective Knowledge of Public Events: The Soviet Era from the Great Purge to Glasnost«, American Journal of Sociology, 105 (4): 913-956. doi:10.1086/210396

Schuman, Howard i Corning, Amy D. (2006). „Comparing Iraq to Vietnam: Recognition, Recall, and the Nature of Cohort Effects«, Public Opinion Quarterly, 70 (1): 78-87. doi:10.1093/poq/nfj010

Schuman, Howard i Rieger, Cheryl (1992). »Historical Analogies, Generational Effects, and Attitudes toward War«, American Sociological Review, 57 (3): 315-326. doi:10.2307/2096238

Schuman, Howard i Rodgers, Willard L. (2004). »Cohorts, Chronology, and Collective Memories«, Public Opinion Quarterly, 68 (2): 217-254. doi:10.1093/poq/ nfh012

Schuman, Howard i Scott, Jacqueline (1989). „Generations and Collective Memories«, American Sociological Review, 54 (3): 359-381. doi:10.2307/2095611

Schwartz, Barry i Schuman, Howard (2005). »History, Commemoration, and Belief: Abraham Lincoln in American Memory, 1945-2001«, American Sociological Review, 70 (2): 183-203. doi:10.1177/000312240507000201

Tomić-Koludrović, Inga (2009). »Pogled u budućnost: sociologija kao multiparadigmatska, refleksivna i javna znanost / A View of the Future: Sociology as a Multiparadigmatic, Reflexive and Public Science«, Revija za sociologiju, 40[39] (3-4): 139-181.

Vučković Juroš, Tanja (2011). »Reporting on the Issues of Research Rigour and Ethics: The Case of Publications Using Qualitative Methods in the Croatian Social Science Journals«, Revija za sociologiju, 41 (2): 161-184. doi:10.5613/ rzs.41.2.2

Wagner-Pacifici, Robin i Schwartz, Barry (1991). »The Vietnam Veterans Memorial: Commemorating a Difficult Past «, American Journal of Sociology, 97 (2): 376-420. doi:10.1086/229783

Wertsch, James V. (2002). Voices of Collective Remembering. Cambridge: Cambridge University Press. 


\title{
Intertwining Research Decisions and Theoretical Foundations: An Example of Collective Memories Research
}

\author{
Tanja VUČKOVIĆ JUROŠ \\ Social Work Study Centre, Faculty of Law, University of Zagreb, Croatia \\ tanja.vuckovic.juros@gmail.com
}

The present paper uses the example of collective memories research to demonstrate how a research decision-making process, a particular approach to the research area and an operationalization of the collective memories issue were theoretically based on three levels. The first, the level of the sociological theoretical perspective - social constructivism in this case - defined the manner in which collective memories were approached and their individualistic conceptualization. Such a conceptualization has been neglected so far in the dominant semiotic and institutionalist approaches to collective memories. The second level, the level of the methodological approach, has resulted in use of qualitative methods within the framework of social constructivism. Finally, the third level encompassed current theoretical developments in the field of collective memories, which led to the "discovery" of a gap in this field and to the formulation of specific research questions. At the end, the present paper attempts to demonstrate how specific answers to the research questions posed in such a way may contribute to current theoretical considerations of the collective memories field, and how they may contribute to fulfilling the observed gap. In this way, the paper shows how a qualitative approach to collective memories has contributed to this field by providing a new understanding of the issue of collective memories formation, which dominant semiotic and institutionalist approaches have been less successful in providing.

Key words: theory, social constructivism, qualitative methods, collective memories, individualistic conceptualization 